\title{
Penerapan Algoritma Fp-Growth Dalam Menentukan Perilaku Konsumen Ghania Mart Muara Bulian
}

\author{
$\underline{\text { Azwar Anas }}$ \\ Program Studi Manajemen, STIE - Graha Karya Muara Bulian \\ Jl. Gajah Mada Muara Bulian-Indonesia \\ azwarzayn@gmail.com
}

\begin{abstract}
Ghania Mart is a minimarket that operates in Muara Bulian, precisely on Jl. Prof. Dr. Sri Sudewi or in front of the Regional Hajj Abdoel Madjid Batoe Regional Hospital Muara Bulian. This mini market is still new because it has been operating since 2020. Although it is new, the minimarket is quite crowded with shoppers, this is due to the selection of the right location from the management of Ghania Mart. The products available at Ghania Mart are more dominated by staples such as rice, vegetable oil, sugar, salt and others. Also available are other products such as instant food and instant drinks with various brands and variations of taste. Ghania Mart operates from 08.00 to 21.00 WIB. The method that I use in this research is library research or labor research. In this study, the authors used data mining enrichment techniques. The algorithm that I use in the addition of this data is the FP-Growth Algorithm. While the software used is Weka Data Mining. The results of this study prove the FP-Growth algorithm has a speed in data processing which is helped from the formation of FP-Tree. Testing using Weka data mining software obtained the 4 best rules. The combination of Mask and Coffee has a $10 \%$ support and confidence reaches $93 \%$.
\end{abstract}

Keywords: Algorithm, FP-Growth, consumen, product, pattern of purchasing goods.

\begin{abstract}
Abstrak
Ghania Mart merupakan salah satu minimarket yang beroperasi di Muara Bulian, tepatnya di J1. Prof. Dr. Sri Sudewi atau depan Rumah Sakit Umum Daerah Haji Abdoel Madjid Batoe Muara Bulian. Minimarket ini tergolong masih baru karena beroperasi sejak tahun 2020. Meskipun baru, minimarket ini cukup ramai dikunjungi oleh konsumen yang berbelanja, hal ini dikarenakan pemilihan lokasi yang tepat dari manajemen Ghania Mart. Produk yang tersedia di Ghania Mart lebih didominasi oleh kebutuhan bahan pokok seperti beras, minyak sayur, gula, garam dan lainnya. Selain itu juga tersedia produk lain seperti makanan instan dan minuman instan dengan berbagai merk dan variasi rasa. Ghania Mart beroperasi mulai dari pukul 08.00 sampai pukul 21.00 WIB. Metode yang penulis gunakan dalam penelitian ini adalah library research atau penelitian labor. Dalam penelitian ini, penulis menggunakan teknik pengayaan data mining. Adapun algoritma yang penulis gunakan dalam penambagnan data ini adalah Algoritma FP-Growth. Sedangkan software yang digunakan adalah Weka Data Mining. Hasil penelitian ini membuktian algoritma FP-Growth memiliki kecepatan dalam pemrosesan data yang terbantu dari pembentukan FP-Tree. Pengujian menggunakan software data mining Weka didapatkan 4 rule terbaik. Kombinasi Masker dan Kopi memiliki support 10\% dan confidence mencapai $93 \%$.
\end{abstract}

Kata kunci : Algoritma, FP-Growth, konsumen, produk, pola pembelian barang.

\section{Pendahuluan}

Ghania Mart merupakan salah satu minimarket yang beroperasi di Muara Bulian, tepatnya di Jl. Prof. Dr. Sri Sudewi atau depan Rumah Sakit Umum Daerah Haji Abdoel Madjid Batoe Muara Bulian. Minimarket ini tergolong masih baru karena beroperasi sejak tahun 2020. Meskipun baru, minimarket ini cukup ramai dikunjungi oleh konsumen yang berbelanja, hal ini dikarenakan pemilihan lokasi yang tepat dari manajemen Ghania Mart. 
Produk yang tersedia di Ghania Mart lebih didominasi oleh kebutuhan bahan pokok seperti beras, minyak sayur, gula, garam dan lainnya. Selain itu juga tersedia produk lain seperti makanan instan dan minuman instan dengan berbagai merk dan variasi rasa. Ghania Mart beroperasi mulai dari pukul 08.00 sampai pukul 21.00 WIB.

Pembelian barang yang dilakukan oleh konsumen tercatat dengan sistem komputerisasi. Catatan pembelian barang tersebut tentu saja beragam berdasarkan profil dari pembeli. Misalnya pembeli wanita cenderung membeli kebutuhan wanita seperti pembalut, tisu, alat make up atau bahkan kebutuhan dapur seperti minyak sayur, garam, gula, kopi, the dan lain sebagainya. Sedangkan pembeli pria cenderung membli barang seperti rokok, korek api atau juga kebutuhan dapur dengan kapasitas yang lebih besar seperti beras atau air minum dalam wadah galon. Kemudian jika pembeli adalah anak-anak cenderung membeli mainan seperti mobil-mobilan, boneka atau buku gambar dan pewarna.

Pembelian barang yang dilakukan oleh konsumen juga beragam dari segi jumlah jenis produk yang dibeli dalam satu transaksi pembelian. Misalnya ada yang membeli tiga jenis produk, ada yang membeli dua jenis produk ada yang hanya membeli satu jenis produk namun dengan kuantitas yang banyak, bahkan ada yang membeli lebih dari empat produk dalam satu transaksi hal ini biasanya terjadi ketika belanja bulanan atau setelah mendapatkan penghasilan.

Semua pola pembelian tersebut tercatat dalam komputer kasir saat pembeli membayar barang yang dibelinya. Hal ini terjadi secara terus-menerus mulai dari beroperasinya Ghania Mart hingga sekarang. Dapat dibayangkan, jika dalam satu hari terjadi dua puluh kali transaksi, maka dalam satu bulan berarti terjadi 600 kali transaksi pembelian barang di Ghania Mart tersebut. Maka dalam satu tahun terjadilah 7.200 transasksi pembelian barang oleh konsumen.

Tumpukan data tersebut tidak ada artinya, atau bahkan hanya menjadi sampah dalam bentuk bongkahan data yang begitu besar. Namun dengan kecanggihan ilmu pengetahuan khususnya penambangan data atau Data Mining yang diaplikasikan dalam teknologi komputer menggunakan software data mining, maka tumpukan data tersebut menghasilkan pengetahuan yang sangat berguna bagi manajemen Ghania Mart. Banyak algoritma yang ditawarkan oleh data mining untuk menghasilkan suatu pengetahuan. Selain itu, juga banyak software data mining yang bisa digunakan untuk mengaplikasikan bongkahan data yang rumit tersebut, sehingga dengan mudah menghasilkan pola untuk kita baca dan kemudian mengambil suatu kesimpulan berharga.

Dalam dunia bisnis, persaingan antar mini market untuk memasarkan produk tidak bisa dilepaskan dari pemanfaatan teknologi informasi. Salah satu sumber informasi yang dapat digunakan untuk membantu kegiatan penjualan adalah sistem database. Cara untuk mendapatkan informasi berharga dari data transaksi adalah dengan menggunakan metode data mining. Dari sinilah penulis tertarik untuk melakukan penelitian terkait tumpukan data pembelian barang di Ghania Mart Muara Bulian yang pada akhirnya diharapkan mampu menampilkan pola pembelian barang oleh konsumen.

Data mining terdiri dari dua kata yaitu data dan mining. Data adalah sekumpulan bahan, alat, teks yang belum mempunyai arti. Biasanya data bersifat tunggal dan kaku. Butuh proses pengolahan yang benar untuk menghasilkan data menjadi informasi. Sedangkan mining diartikan sebagai penambangan atau penggalian informasi. Sehingga secara ringkas data mining adalah penambangan data menjadi informasi. Data mining adalah suatu istilah yang digunakan untuk menguraikan penemuan pengetahuan di dalam database. Data mining adalah proses yang menggunakan teknik statistik, matematika, kecerdasan buatan, dan machine learning untuk mengekstrasksi dan mengidentifikasi informasi yang bermanfaat dan pengetahuan yang terkait dari berbagai database besar [1].

Data mining sebagai proses untuk mendapatkan informasi yang berguna dari gudang basis data yang besar dan dapat diartikan sebagai pengekstrakan informasi baru yang diambil dari bongkahan data besar yang membantu dalam pengambilan keputusan. Istilah data mining kadang disebut juga Knowledge Discovery in Database (KDD) [2]. Secara sederhana data mining adalah penambangan atau penemuan informasi baru dengan mencari pola atau aturan tertentu dari sejumlah data yang sangat besar. Data mining juga disebut sebagai serangkaian proses untuk menggali nilai tambah berupa pengetahuan yang selama ini tidak diketahui secara manual dari suatu kumpulan data [3]. 
Analisis asosiasi atau association rule mining adalah teknik data mining untukmenemukan aturan assosiatif antara suatu kombinasi item. Contoh aturan assosiatif dari analisa pembelian di suatu pasar swalayan adalah dapat diketahuinya berapa besar kemungkinan seorang pelanggan membeli roti bersamaan dengan susu. Dengan pengetahuan tersebut pemilik pasar swalayan dapat mengatur penempatan barangnya atau merancang kampanye pemasaran dengan memakai kupon diskon untuk kombinasi barang tertentu. Oleh karena analisis asosiasi menjadi terkenal karena aplikasinya untuk menganalisa isi keranjang belanja di pasar swalayan, analisis asosiasi juga sering disebut dengan istilah market basket analysis, yang artinya adalah suatu analisis atas perilaku konsumen secara spesifik dari suatu golongan atau kelompok tertentu [4].

Data mining menawarkan banyak algoritma yang dapat digunakan untuk menggali suatu kaidah asosiasi, salah satunya adalah algoritma Frequent Pattern Growth (FP-Growth). Algoritma FP-Growth merupakan salah satu alternatif algoritma yang cukup efektif untuk mencari himpunan data yang paling sering muncul (frequent itemset) dalam sebuah kumpulan data yang besar [5]. Algoritma FP-Growth merupakan pengembangan dari algoritma FP-Growth. Sehingga kekurangan dari algoritma FP-Growth diperbaiki oleh algoritma FP-Growth [6]. FP-Growth menggunakan pendekatan yang berbeda dari paradigma yang digunakan pada algoritma FP-Growth [7].

FP-Growth menggunakan strategi divide-conquer sehingga algoritma ini hanya membutuhkan dua kali scanning database. Contoh $\mathrm{I}=\{\mathrm{i} 1, \mathrm{i} 2, \mathrm{I} 3, \ldots, \mathrm{In}\}$ adalah sekumpulan dari data item dan basis data transaksi $\mathrm{T}=\{\mathrm{t} 1, \mathrm{t} 2, \mathrm{t} 3, \ldots, \mathrm{tn}\}$, setiap transaksi $\mathrm{t} 1$ berisi bagian dari item I. Scanning pertama dilakukan ketika support count (jumlah transaksi yang mengandung itemset tertentu) sudah ditentukan diawal, contohnya t1 memiliki item i1, i2 kemudian tentukan support count $=2$. Untuk menentukan support adalah berdasarkan kebutuhan karena support ini akan berpengaruh pada hasil FP-Tree yang dibuat dan hasil support dan confidence pada association rule. Semakin supportcount bernilai tinggi 100\% atau 10 maka akan sedikit node pada FP-Tree dan support-confidence akan sedikit menampilkan hasil pola hubungan antara item[2].

Algoritma FP-Growth memiliki tiga tahapan utama [8], yaitu:

1. Tahap pembangkitan Conditional Pattern Base, merupakan sub-database yang berisi prefixpath dan suffix pattern (pola akhiran);

2. Tahap pembangkitan Conditional FP-Tree, dimana pada tahap ini support count dari setiap item untuk conditional pattern base dijumlahkan;

3. Tahap pencarian Frequent Itemset, merupakan lintasan tunggal (single path), kemudian didapatkan frequent itemset dengan melakukan kombinasi item untuk conditional FP-Tree.

Penulis telah melakukan analisis terhadap beberapa artikel terkait dengan penelitian yang dibahas, diantaranya:

1. Penerapan Metode Association Rule Untuk Menganalisa Pola Pemakaian Bahan Kimia Di Laboratorium Menggunakan Algoritma FP-Growth (Studi Kasus di Laboratorium Kimia PT. PLN (Persero) Sektor Pembangkitan Belawan Medan) [9]. Artikel ini juga menggunakan algoritma FPGrowth, dimana hasil yang didapatkan adalah ada 16 aturan asosiasi yang terjadi.

2. Implementasi Algoritma FP-Growth Pada Aplikasi Prediksi Persediaan Sepeda Motor (Studi Kasus PT. Pilar Deli Labumas) [10]. Artikel ini masih menggunakan algoritma FP-Growth dalam prediksi persediaan sepeda motor dengan hasil analisis support tertinggi $12 \%$ dan confidence tertinggi $16 \%$.

\section{Metode Penelitian}

Pada bagian ini akan diuraikan kerangka penelitian, kerangka ini merupakan langkah-langkah yang akan dilakukan dalam penyelesaian masalah yang akan dibahas. 


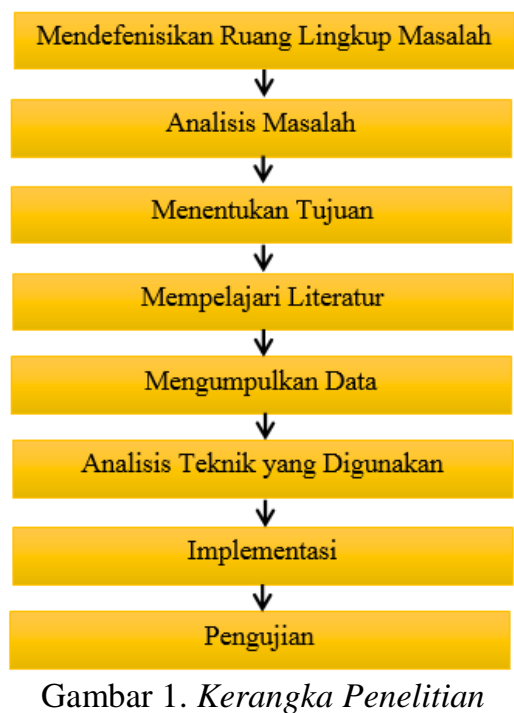

Berdasarkan kerangka pada gambar 1, maka masing-masing tahapannya dapat diuraikan seperti berikut ini :

1. Mendefinisikan Ruang Lingkup Masalah

Ruang lingkup masalah yang akan diteliti harus ditentukan terlebih dahulu, karena tanpa mampu menentukan serta mendefinisikan batasan masalah yang akan diteliti, maka tidak akan pernah didapat suatu solusi yang terbaik dari masalah tersebut. Jadi langkah pertama ini adalah langkah awal yang terpenting dalam penulisan ini.

2. Analisis Masalah

Langkah analisis masalah adalah untuk dapat memahami masalah yang telah ditentukan ruang lingkup atau batasannya. Dengan menganalisa masalah yang telah ditentukan tersebut, maka diharapkan masalah dapat dipahami dengan baik. Pada bagian ini digambarkan proses untuk mendapatkan perilaku konsumen Ghania Mart menggunakan algoritma FP-Growth. Disamping itu juga diuraikan tentang kebutuhan data untuk menggali kaidah asosiasi. Dari hasil analisis tersebut, maka algoritma FP-Growth hendaknya mampu menampilkan perilaku konsumen tersebut dengan baik.

3. Penentuan Tujuan

Berdasarkan pemahaman dari masalah, maka ditentukan tujuan yang akan dicapai dari penulisan ini. Pada tujuan ini ditentukan target yang dicapai, terutama yang dapat mengatasi masalah-masalah yang ada.

4. Mempelajari Literatur

Untuk mencapai tujuan, maka dipelajari berbagai literatur yang relevan dengna masalah yang diteliti. Kemudian literatur-literatur yang dipelajari tersebut diseleksi untuk dapat ditentukan literaturliteratur mana yang akan digunakan dalam penelitian.Literatur diambil dari internet, yang berupa artikel dan jurnal ilmiah tentang data mining, association rule dan algoritma FP-Growth, serta bahan bacaan lain yang mendukung penelitian.

5. Pengumpulan Data dan Informasi

Dalam pengumpulan data dilakukan observasi yaitu pengamatan secara langsung di tempat penelitian sehingga permasalahan yang ada dapat diketahui dengan jelas. Kemudian dilakukan interview yang bertujuan untuk mendapatkan informasi atau data yang dibutuhkan. Selain itu juga dilakukan studi kepustakaan yaitu dengan membaca buku-buku yang menunjang dalam melakukan analisa terhadap data dan informasi yang didapat. Adapun data-data yang diperlukan dalam penelitian ini adalah data belanja konsumen Ghania Mart Muara Bulian.

6. Analisis Teknik yang digunakan.

Bagian ini bertujuan untuk menganalisis dan memahami teknik yang akan digunakan dalam pengolahan data yang telah diperoleh dari tempat penelitian, terutama pada proses, yang mana teknik yang digunakan untuk pengolahan data dengan algoritma FP-Growth.

7. Implementasi

Setelah dilakukan analisis teknik yang digunakan, maka dilakukan implementasi terhadap software dalam hal ini adalah software data mining Weka. Tentu saja penerapan analisis pada software 
tersebut menggunakan algoritma FP-Growth. Jika penerapan sistem sudah berjalan dengan lancar dan akurat, maka sistem dapat diimplementasikan sesuai dengan kebutuhan.

8. Pengujian

Pengujian dilakukan untuk mendapatkan hasil yang sesuai dengan melakukan perbandingan antara perhitungan manual dan komputerisasi, berikut ini langkah-langkah pengujian yang akan dilakukan :

a. Melakukan pengujian algoritma FP-Growth terhadap data data pembelian konsumen secara manual.

b. Setelah dilakukan perhitungan manual, selanjutnya dilakukan perhitungan menggunakan software data mining Weka dengan memasukkan data-data dan diproses menggunakan aturan asosiasi.

c. Tahap terakhir adalah melakukan perbandingan antara perhitungan manual dengan komputerisasi, jika hasil yang dicapai sama atau hampir sama, maka data yang diproses dan teknik yang digunakan telah benar.

\section{Hasil Penelitian}

\subsection{Pemrosesan Data menggunakan Algoritma FP-Growth}

Dalam penelitian ini, penulis melakukan analisis terhadap 30 data transaksi pembelian konsumen Ghania Mart Muara Bulian. Penulis melakukan analisis terhadap data barang-barang yang dibeli oleh konsumen tersebut. Data yang diolah dalam penelitian ini berjumlah 19 jenis barang yang dibeli oleh konsumen. Data tersebut dapat dilihat pada tabel berikut.

\section{Tabel 1. Data Transaksi Barang}

\begin{tabular}{|c|c|c|c|c|c|c|c|c|c|c|c|c|c|c|c|c|c|c|c|c|}
\hline $\begin{array}{l}\text { TRAN } \\
\text { SAKSI }\end{array}$ & $\begin{array}{c}\text { VITAC } \\
\text { IMIN }\end{array}$ & \begin{tabular}{|c} 
HAND \\
SANIT \\
IZER \\
\end{tabular} & \begin{tabular}{|c} 
MASK \\
ER
\end{tabular} & KOPI & ROTI & \begin{tabular}{|l} 
INDO \\
MIIE
\end{tabular} & $\begin{array}{c}\text { MENTE } \\
\text { GA }\end{array}$ & $\underset{\mathrm{N}}{\mathrm{SABU}}$ & TEH & GULA & $\left|\begin{array}{c}\text { ROKO } \\
\text { K }\end{array}\right|$ & $\underset{\mathrm{G}}{\text { TEPUN }}$ & $\begin{array}{c}\text { BERA } \\
\mathrm{S}\end{array}$ & $\begin{array}{c}\text { BLMO } \\
\text { LI }\end{array}$ & $\begin{array}{c}\text { GARA } \\
\text { M }\end{array}$ & PENA & $\begin{array}{c}\text { PERM } \\
\text { EN }\end{array}$ & BUKU & \begin{tabular}{|c|} 
SHAM \\
POO
\end{tabular} & \multirow[t]{2}{*}{$\begin{array}{l}\text { JUM } \\
\text { LAH }\end{array}$} \\
\hline KODE & A & B & C & D & E & $\mathbf{F}$ & G & $\mathrm{H}$ & I & $\mathrm{J}$ & $\mathrm{K}$ & L & M & $\mathrm{N}$ & 0 & P & $\mathbf{Q}$ & $\mathbf{R}$ & $\mathrm{s}$ & \\
\hline 1 & $\mathrm{Y}$ & $\mathrm{Y}$ & $\mathrm{T}$ & $\mathrm{T}$ & $T$ & $\mathrm{~T}$ & $\mathrm{Y}$ & $\mathrm{T}$ & $\mathrm{T}$ & $\mathrm{Y}$ & $\mathrm{T}$ & $\mathrm{T}$ & $\mathrm{T}$ & $T$ & $\mathrm{~T}$ & $\mathrm{~T}$ & $\mathrm{~T}$ & $\mathrm{~T}$ & $\mathrm{Y}$ & 5 \\
\hline 2 & $T$ & $T$ & $T$ & $\mathrm{~T}$ & $T$ & $\mathrm{~T}$ & $\mathrm{~T}$ & $T$ & $\mathrm{Y}$ & $\mathrm{T}$ & $\mathrm{T}$ & $\mathrm{T}$ & $\mathrm{Y}$ & $\mathrm{T}$ & $\mathrm{T}$ & $\mathrm{T}$ & $\mathrm{T}$ & $\mathrm{T}$ & $\mathrm{T}$ & 2 \\
\hline 3 & $\mathrm{~T}$ & $\mathrm{~T}$ & $\mathrm{Y}$ & $\mathrm{Y}$ & $\mathrm{T}$ & $\mathrm{T}$ & $\mathrm{T}$ & $\mathrm{T}$ & $\mathrm{T}$ & $\mathrm{T}$ & $\mathrm{T}$ & $\mathrm{Y}$ & $\mathrm{T}$ & $\mathrm{T}$ & $\mathrm{T}$ & $\mathrm{T}$ & $\mathrm{T}$ & $\mathrm{T}$ & $\mathrm{T}$ & 3 \\
\hline 4 & $\mathrm{Y}$ & $\mathrm{T}$ & $\mathrm{Y}$ & $\mathrm{T}$ & $\mathrm{T}$ & $\mathrm{Y}$ & $\mathrm{T}$ & $\mathrm{T}$ & $\mathrm{T}$ & $\mathrm{T}$ & $\mathrm{T}$ & $\mathrm{T}$ & $\mathrm{T}$ & $\mathrm{T}$ & $\mathrm{Y}$ & $\mathrm{T}$ & $\mathrm{T}$ & $\mathrm{T}$ & $\mathrm{Y}$ & 5 \\
\hline 5 & $\mathrm{Y}$ & $\mathrm{T}$ & $\mathrm{T}$ & $\mathrm{T}$ & $T$ & $T$ & $\mathrm{Y}$ & $\mathrm{T}$ & $\mathrm{T}$ & $\mathrm{T}$ & $\mathrm{T}$ & $\mathrm{Y}$ & $\mathrm{T}$ & $\mathrm{T}$ & $\mathrm{T}$ & $\mathrm{T}$ & $\mathrm{T}$ & $\mathrm{T}$ & $\mathrm{T}$ & 3 \\
\hline 6 & $\mathrm{~T}$ & $\mathrm{Y}$ & $\mathrm{T}$ & $\mathrm{T}$ & $\mathrm{T}$ & $\mathrm{T}$ & $\mathrm{T}$ & $\mathrm{T}$ & $\mathrm{Y}$ & $\mathrm{T}$ & $\mathrm{T}$ & $\mathrm{T}$ & $\mathrm{T}$ & $\mathrm{T}$ & $\mathrm{T}$ & $\mathrm{T}$ & $\mathrm{T}$ & $\mathrm{T}$ & $\mathrm{Y}$ & 3 \\
\hline 7 & $\mathrm{Y}$ & $\mathrm{T}$ & $\mathrm{T}$ & $\mathrm{T}$ & $\mathrm{T}$ & $\mathrm{Y}$ & $\mathrm{T}$ & $\mathrm{T}$ & $\mathrm{Y}$ & $\mathrm{T}$ & $\mathrm{T}$ & $\mathrm{T}$ & $\mathrm{Y}$ & $\mathrm{T}$ & $\mathrm{T}$ & $\mathrm{T}$ & $\mathrm{T}$ & $\mathrm{T}$ & $\mathrm{T}$ & 4 \\
\hline 8 & $\mathrm{Y}$ & $\mathrm{T}$ & $\mathrm{T}$ & $\mathrm{T}$ & $\mathrm{Y}$ & $\mathrm{T}$ & $\mathrm{T}$ & $\mathrm{T}$ & $\mathrm{T}$ & $\mathrm{T}$ & $\mathrm{T}$ & $\mathrm{T}$ & $\mathrm{T}$ & $\mathrm{T}$ & $\mathrm{T}$ & $\mathrm{T}$ & $\mathrm{T}$ & $\mathrm{T}$ & $\mathrm{T}$ & 2 \\
\hline 9 & $\mathrm{~T}$ & $\mathrm{~T}$ & $\mathrm{~T}$ & $\mathrm{~T}$ & $\mathrm{~T}$ & $\mathrm{~T}$ & $\mathrm{~T}$ & $\mathrm{~T}$ & $\mathrm{~T}$ & $\mathrm{~T}$ & $\mathrm{~T}$ & $\mathrm{~T}$ & $\mathrm{~T}$ & $\mathrm{Y}$ & $\mathrm{Y}$ & $\mathrm{T}$ & $\mathrm{T}$ & $\mathrm{T}$ & $\mathrm{T}$ & 2 \\
\hline 10 & $\mathrm{~T}$ & $\mathrm{~T}$ & $T$ & $\mathrm{~T}$ & $T$ & $\mathrm{~T}$ & $\mathrm{~T}$ & $T$ & $\mathrm{~T}$ & $T$ & $\mathrm{~T}$ & $\mathrm{~T}$ & $\mathrm{Y}$ & $\mathrm{T}$ & $\mathrm{Y}$ & $\mathrm{Y}$ & $\mathrm{T}$ & $\mathrm{T}$ & $\mathrm{T}$ & 3 \\
\hline 11 & $\mathrm{~T}$ & $\mathrm{~T}$ & $\mathrm{~T}$ & $\mathrm{~T}$ & $\mathrm{Y}$ & $\mathrm{Y}$ & $\mathrm{T}$ & $\mathrm{T}$ & $T$ & $\mathrm{~T}$ & $\mathrm{~T}$ & $\mathrm{~T}$ & $T$ & $\mathrm{~T}$ & $\mathrm{~T}$ & $\mathrm{~T}$ & $\mathrm{~T}$ & $\mathrm{~T}$ & $\mathrm{~T}$ & 2 \\
\hline 12 & $\mathrm{Y}$ & $\mathrm{T}$ & $\mathrm{T}$ & $\mathrm{T}$ & $\mathrm{T}$ & $\mathrm{T}$ & $\mathrm{Y}$ & $\mathrm{Y}$ & $\mathrm{T}$ & $\mathrm{T}$ & $\mathrm{T}$ & $\mathrm{T}$ & $\mathrm{T}$ & $\mathrm{T}$ & $\mathrm{T}$ & $\mathrm{T}$ & $\mathrm{T}$ & $\mathrm{Y}$ & $\mathrm{T}$ & 4 \\
\hline 13 & $\mathrm{~T}$ & $\mathrm{~T}$ & $\mathrm{Y}$ & $\mathrm{Y}$ & $\mathrm{Y}$ & $\mathrm{T}$ & $\mathrm{T}$ & $\mathrm{T}$ & $\mathrm{T}$ & $\mathrm{T}$ & $\mathrm{T}$ & $\mathrm{T}$ & $\mathrm{T}$ & $\mathrm{T}$ & $\mathrm{T}$ & $\mathrm{T}$ & $\mathrm{T}$ & $\mathrm{T}$ & $\mathrm{Y}$ & 4 \\
\hline 14 & $\mathrm{Y}$ & $T$ & $\mathrm{~T}$ & $\mathrm{~T}$ & $\mathrm{~T}$ & $\mathrm{Y}$ & $\mathrm{Y}$ & $\mathrm{T}$ & $\mathrm{T}$ & $\mathrm{T}$ & $\mathrm{T}$ & $\mathrm{T}$ & $\mathrm{T}$ & $\mathrm{T}$ & $\mathrm{T}$ & $\mathrm{T}$ & $\mathrm{T}$ & $\mathrm{T}$ & $\mathrm{T}$ & 3 \\
\hline 15 & $\mathrm{~T}$ & $\mathrm{~T}$ & $\mathrm{~T}$ & $\mathrm{~T}$ & $\mathrm{~T}$ & $\mathrm{~T}$ & $\mathrm{~T}$ & $\mathrm{Y}$ & $\mathrm{T}$ & $\mathrm{T}$ & $\mathrm{T}$ & $\mathrm{T}$ & $\mathrm{Y}$ & $\mathrm{T}$ & $\mathrm{T}$ & $\mathrm{T}$ & $\mathrm{T}$ & $\mathrm{T}$ & $\mathrm{T}$ & 2 \\
\hline 16 & $\mathrm{Y}$ & $\mathrm{Y}$ & $\mathrm{T}$ & $\mathrm{T}$ & $\mathrm{T}$ & $\mathrm{T}$ & $\mathrm{T}$ & $\mathrm{T}$ & $\mathrm{Y}$ & $\mathrm{T}$ & $\mathrm{T}$ & $\mathrm{T}$ & $\mathrm{T}$ & $\mathrm{T}$ & $\mathrm{Y}$ & $\mathrm{T}$ & $\mathrm{T}$ & $\mathrm{T}$ & $\mathrm{T}$ & 4 \\
\hline 17 & $\mathrm{~T}$ & $\mathrm{Y}$ & $\mathrm{T}$ & $\mathrm{T}$ & $\mathrm{T}$ & $\mathrm{T}$ & $\mathrm{T}$ & $\mathrm{T}$ & $\mathrm{T}$ & $\mathrm{T}$ & $\mathrm{T}$ & $\mathrm{T}$ & $\mathrm{Y}$ & $\mathrm{T}$ & $\mathrm{T}$ & $\mathrm{T}$ & $\mathrm{T}$ & $\mathrm{Y}$ & $\mathrm{T}$ & 3 \\
\hline 18 & $\mathrm{~T}$ & $T$ & $\mathrm{~T}$ & $\mathrm{~T}$ & $\mathrm{~T}$ & $\mathrm{~T}$ & $\mathrm{~T}$ & $T$ & $\mathrm{Y}$ & $\mathrm{T}$ & $\mathrm{T}$ & $\mathrm{T}$ & $\mathrm{T}$ & $\mathrm{T}$ & $\mathrm{T}$ & $\mathrm{T}$ & $\mathrm{T}$ & $\mathrm{T}$ & $\mathrm{Y}$ & 2 \\
\hline 19 & $\mathrm{~T}$ & $\mathrm{~T}$ & $\mathrm{~T}$ & $\mathrm{~T}$ & $\mathrm{Y}$ & $\mathrm{T}$ & $\mathrm{Y}$ & $\mathrm{T}$ & $\mathrm{T}$ & $\mathrm{T}$ & $\mathrm{T}$ & $\mathrm{T}$ & $\mathrm{T}$ & $\mathrm{T}$ & $\mathrm{T}$ & $\mathrm{T}$ & $\mathrm{Y}$ & $\mathrm{T}$ & $\mathrm{T}$ & 3 \\
\hline 20 & $\mathrm{~T}$ & $\mathrm{~T}$ & $\mathrm{Y}$ & $\mathrm{Y}$ & $\mathrm{T}$ & $\mathrm{T}$ & $\mathrm{T}$ & $\mathrm{T}$ & $\mathrm{T}$ & $\mathrm{T}$ & $\mathrm{T}$ & $\mathrm{T}$ & $\mathrm{Y}$ & $\mathrm{T}$ & $\mathrm{T}$ & $\mathrm{T}$ & $\mathrm{T}$ & $\mathrm{T}$ & $\mathrm{Y}$ & 4 \\
\hline 21 & $\mathrm{~T}$ & $\mathrm{~T}$ & $\mathrm{~T}$ & $\mathrm{~T}$ & $\mathrm{~T}$ & $\mathrm{~T}$ & $\mathrm{~T}$ & $\mathrm{~T}$ & $\mathrm{~T}$ & $\mathrm{~T}$ & $\mathrm{~T}$ & $\mathrm{Y}$ & $\mathrm{T}$ & $\mathrm{T}$ & $\mathrm{T}$ & $\mathrm{T}$ & $\mathrm{T}$ & $\mathrm{Y}$ & $\mathrm{T}$ & 2 \\
\hline 22 & $\mathrm{Y}$ & $\mathrm{T}$ & $\mathrm{T}$ & $\mathrm{T}$ & $\mathrm{T}$ & $\mathrm{T}$ & $\mathrm{T}$ & $\mathrm{T}$ & $\mathrm{T}$ & $\mathrm{T}$ & $\mathrm{T}$ & $\mathrm{T}$ & $\mathrm{T}$ & $\mathrm{T}$ & $\mathrm{T}$ & $\mathrm{T}$ & $\mathrm{Y}$ & $\mathrm{T}$ & $\mathrm{T}$ & 2 \\
\hline 23 & $\mathrm{Y}$ & $\mathrm{Y}$ & $\mathrm{T}$ & $\mathrm{T}$ & $\mathrm{T}$ & $\mathrm{T}$ & $\mathrm{T}$ & $\mathrm{T}$ & $\mathrm{T}$ & $\mathrm{T}$ & $\mathrm{T}$ & $\mathrm{Y}$ & $\mathrm{T}$ & $\mathrm{T}$ & $\mathrm{T}$ & $\mathrm{T}$ & $\mathrm{T}$ & $\mathrm{T}$ & $\mathrm{T}$ & 3 \\
\hline 24 & $\mathrm{~T}$ & $\mathrm{~T}$ & $\mathrm{~T}$ & $\mathrm{~T}$ & $\mathrm{Y}$ & $\mathrm{T}$ & $\mathrm{T}$ & $\mathrm{T}$ & $\mathrm{T}$ & $\mathrm{T}$ & $\mathrm{T}$ & $\mathrm{T}$ & $\mathrm{T}$ & $\mathrm{T}$ & $\mathrm{T}$ & $\mathrm{T}$ & $\mathrm{T}$ & $\mathrm{Y}$ & $\mathrm{Y}$ & 3 \\
\hline 25 & $\mathrm{Y}$ & $\mathrm{T}$ & $\mathrm{T}$ & $\mathrm{T}$ & $\mathrm{T}$ & $\mathrm{T}$ & $\mathrm{T}$ & $\mathrm{T}$ & $\mathrm{T}$ & $\mathrm{T}$ & $\mathrm{T}$ & $\mathrm{Y}$ & $\mathrm{Y}$ & $\mathrm{T}$ & $\mathrm{T}$ & $\mathrm{T}$ & $\mathrm{T}$ & $\mathrm{T}$ & $\mathrm{Y}$ & 4 \\
\hline 26 & $\mathrm{~T}$ & $\mathrm{Y}$ & $\mathrm{T}$ & $\mathrm{T}$ & $\mathrm{T}$ & $\mathrm{Y}$ & $\mathrm{T}$ & $\mathrm{T}$ & $\mathrm{T}$ & $\mathrm{T}$ & $\mathrm{T}$ & $\mathrm{T}$ & $\mathrm{T}$ & $\mathrm{T}$ & $\mathrm{T}$ & $\mathrm{T}$ & $\mathrm{T}$ & $\mathrm{T}$ & $\mathrm{T}$ & 2 \\
\hline 27 & $\mathrm{Y}$ & $\mathrm{T}$ & $\mathrm{T}$ & $\mathrm{T}$ & $\mathrm{T}$ & $\mathrm{T}$ & $\mathrm{T}$ & $\mathrm{T}$ & $\mathrm{T}$ & $\mathrm{T}$ & $\mathrm{T}$ & $\mathrm{T}$ & $\mathrm{T}$ & $\mathrm{T}$ & $\mathrm{T}$ & $\mathrm{Y}$ & $\mathrm{T}$ & $\mathrm{T}$ & $\mathrm{T}$ & 2 \\
\hline 28 & $\mathrm{~T}$ & $\mathrm{~T}$ & $\mathrm{~T}$ & $\mathrm{~T}$ & $\mathrm{~T}$ & $\mathrm{~T}$ & $\mathrm{Y}$ & $\mathrm{T}$ & $\mathrm{T}$ & $\mathrm{T}$ & $\mathrm{Y}$ & $\mathrm{T}$ & $\mathrm{T}$ & $\mathrm{T}$ & $\mathrm{T}$ & $\mathrm{T}$ & $\mathrm{T}$ & $\mathrm{T}$ & $\mathrm{Y}$ & 3 \\
\hline 29 & $\mathrm{~T}$ & $\mathrm{Y}$ & $\mathrm{Y}$ & $\mathrm{T}$ & $\mathrm{T}$ & $\mathrm{T}$ & $\mathrm{T}$ & $\mathrm{T}$ & $\mathrm{Y}$ & $\mathrm{T}$ & $\mathrm{T}$ & $\mathrm{T}$ & $\mathrm{T}$ & $\mathrm{Y}$ & $\mathrm{T}$ & $\mathrm{T}$ & $\mathrm{T}$ & $\mathrm{T}$ & $\mathrm{T}$ & 4 \\
\hline 30 & $\mathrm{~T}$ & $\mathrm{~T}$ & $\mathrm{~T}$ & $\mathrm{~T}$ & $\mathrm{Y}$ & $\mathrm{T}$ & $\mathrm{T}$ & $\mathrm{T}$ & $\mathrm{T}$ & $\mathrm{Y}$ & $\mathrm{Y}$ & $\mathrm{T}$ & $\mathrm{T}$ & $\mathrm{T}$ & $\mathrm{T}$ & $\mathrm{T}$ & $\mathrm{T}$ & $\mathrm{T}$ & $\mathrm{Y}$ & 4 \\
\hline $\begin{array}{c}\text { JUMI } \\
\mathbf{A H}\end{array}$ & 12 & 7 & 5 & 3 & 6 & 5 & 6 & 2 & 6 & 2 & 2 & 5 & 7 & 2 & 4 & 2 & 2 & 4 & 10 & \\
\hline
\end{tabular}

Dari data di atas, transaksi dengan variabel huruf $\mathrm{Y}$ berarti barang yang dibeli, sedangkan huruf $\mathrm{T}$ menyatakan barang yang tidak dibeli oleh konsumen dalam suatu transaksi. Dapat dilihat bahwa jumlah jenis barang yang dibeli oleh konsumen berjumlah 19 jenis. Jenis barang yang paling sering dibeli adalah Vitacimin dengan frekuensi 12 kali sedangkan yang plaing sedikit adalah Sabun, Gula, Rokok, Bimoli, Pena dan Permen yang punya frekuensi 2 kali. Adapun transaksi yang memiliki himpunan terbesar adalah 
transaksi 1 dan 4 yaitu 5 jenis barang, sedangkan yang paling sedikit adalah 2, 8, 9, 11, 15, 18, 21, 22, 26 dan 27 yang hanya memiliki 2 jenis barang dalam satu transaksi. Dengan mengacu pada tabel di atas, dapat kita lihat nilai support setiap transaksi, sebagimana tabel berikut.

Tabel 2. Nilai Support Barang

\begin{tabular}{ccc}
\hline KODE BARANG & FREKUENSI & SUPPORT \\
\hline A & 12 & $40 \%$ \\
B & 7 & $23 \%$ \\
C & 5 & $17 \%$ \\
D & 3 & $10 \%$ \\
E & 6 & $20 \%$ \\
F & 5 & $17 \%$ \\
G & 6 & $20 \%$ \\
H & 2 & $7 \%$ \\
I & 6 & $20 \%$ \\
J & 2 & $7 \%$ \\
K & 2 & $7 \%$ \\
L & 5 & $17 \%$ \\
M & 7 & $23 \%$ \\
N & 2 & $7 \%$ \\
O & 4 & $13 \%$ \\
P & 2 & $7 \%$ \\
Q & 2 & $7 \%$ \\
R & 4 & $13 \%$ \\
S & 10 & $33 \%$ \\
\hline
\end{tabular}

Dari tabel di atas, dapat dilihat bahwa nilai Support tertinggi dimiliki oleh kode barang A yaitu $40 \%$ dari total transaksi yang diamati. Sedangkan nilai Support terendah adalah kode barang H, J, K, N, R dan Q yang hanya $7 \%$.

Langkah selanjutnya adalah menyusun daftar barang berdasarkan frekuensi tertinggi pada setiap transaksi, sebagaimana tabel berikut.

Tabel 3. Urutan Transaksi Tertinggi

\begin{tabular}{cc}
\hline Transaksi & Barang \\
\hline 1 & A,S,B,G,J \\
2 & M,I \\
3 & C,L,D \\
4 & A,S,C,F,O \\
5 & A,G,L \\
6 & S,B,I \\
7 & A,M,I,F \\
8 & A,E \\
9 & O,N \\
10 & M,O,P
\end{tabular}




\begin{tabular}{cc}
11 & E,F \\
12 & A,G,R,H \\
13 & S,E,C,D \\
14 & A,G,F \\
15 & M,H \\
16 & A,B,I,O \\
17 & B,M,R \\
18 & S,I \\
19 & E,G,Q \\
20 & S,M,C,D \\
21 & L,R \\
22 & A,Q \\
23 & A,B,L \\
24 & S,E,R \\
25 & A,S,M,L \\
26 & B,F \\
27 & A,P \\
28 & S,G,K \\
29 & B,I,C,N \\
30 & S,E,J,K \\
\hline
\end{tabular}

\subsection{Pembentukan FP Tree}

Berdasarkan Tabel 3 di atas, langkah selanjutnya adalah pembentukan FP-Tree, sebagaimana gambar berikut.

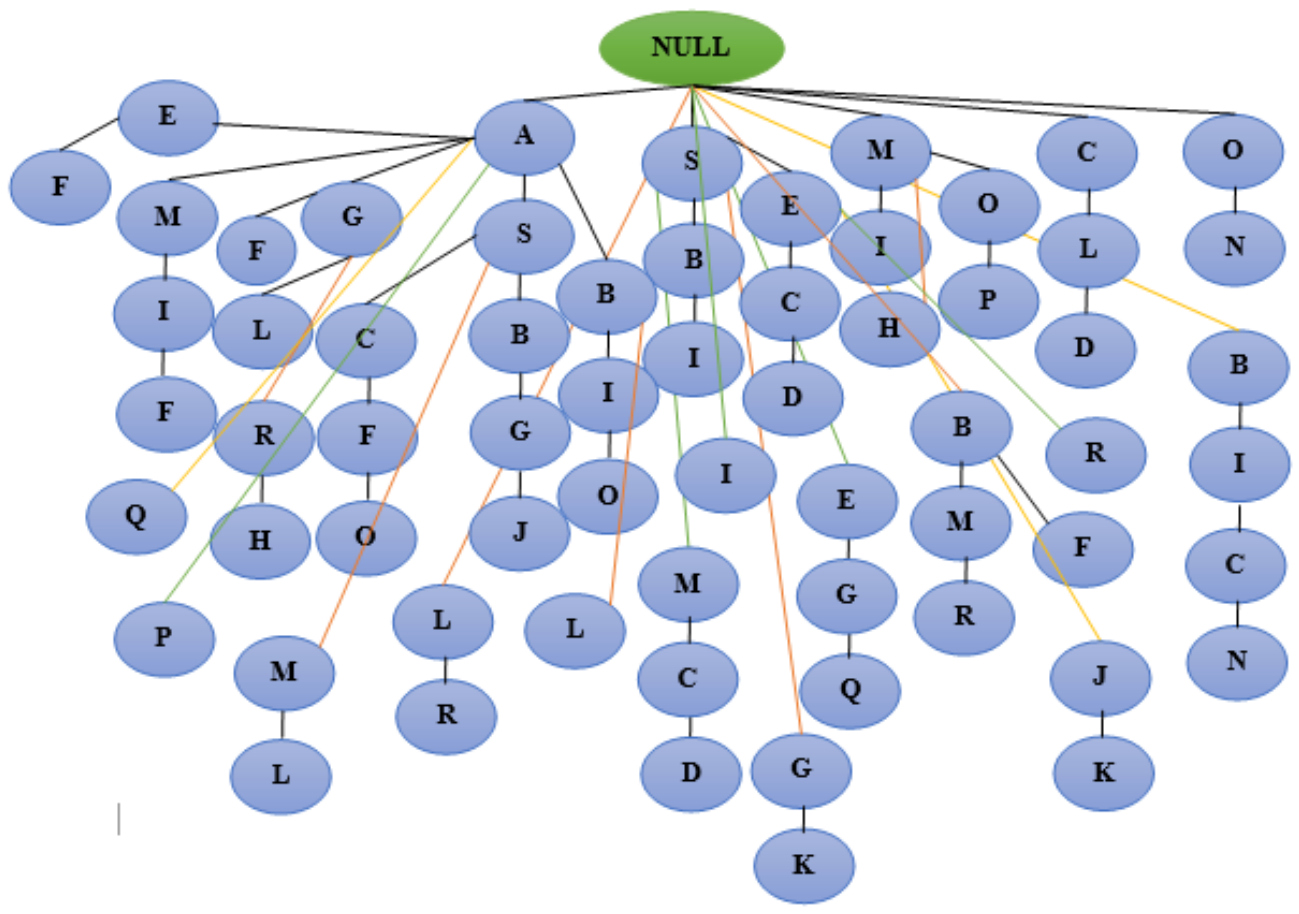

Gambar 2. Pembentukan FP-Tree 


\subsection{Pembangkitan Conditional Pattern Base}

Berdasarkan gambar 2 di atas, maka dilakukan pembangkitan Conditional Pattern Base berdasarkan lintasan yang berakhiran nilai support terkecil sebagaimana tabel berikut.

Tabel. 4. Pembangkitan Conditional Pattern Base

\begin{tabular}{cl}
\hline Item & Conditional Pattern Base \\
\hline $\mathrm{H}$ & $\{\mathrm{A}, \mathrm{G}, \mathrm{R}, \mathrm{H}\},\{\mathrm{M}, \mathrm{H}\}$ \\
$\mathrm{J}$ & $\{\mathrm{A}, \mathrm{S}, \mathrm{B}, \mathrm{G}, \mathrm{J}\}$ \\
$\mathrm{K}$ & $\{\mathrm{S}, \mathrm{G}, \mathrm{K}\},\{\mathrm{M}, \mathrm{I}, \mathrm{J}, \mathrm{K}\}$ \\
$\mathrm{N}$ & $\{\mathrm{O}, \mathrm{N}\},\{\mathrm{B}, \mathrm{I}, \mathrm{C}, \mathrm{N}\}$ \\
$\mathrm{P}$ & $\{\mathrm{A}, \mathrm{P}\},\{\mathrm{M}, \mathrm{O}, \mathrm{P}\}$ \\
$\mathrm{Q}$ & $\{\mathrm{A}, \mathrm{Q}\},\{\mathrm{E}, \mathrm{G}, \mathrm{Q}\}$ \\
\hline
\end{tabular}

\subsection{Pembangkitan Conditional FP-Tree}

Berikutnya adalah mencari lintasan dengan akhiran yang sama (suffix) sebagaimana tabel berikut.

Tabel 5. Pembangkitan Conditional FP-Tree

\begin{tabular}{|c|l|}
\hline Suffix & \multicolumn{1}{|c|}{ Frequent Itemset } \\
\hline F & $\{\mathrm{A}, \mathrm{F}\},\{\mathrm{A}, \mathrm{M}, \mathrm{I}, \mathrm{F}\},\{\mathrm{B}, \mathrm{F}\}$ \\
\hline $\mathrm{Q}$ & $\{\mathrm{A}, \mathrm{Q}\},\{\mathrm{E}, \mathrm{G}, \mathrm{Q}\}$ \\
\hline $\mathrm{P}$ & $\{\mathrm{A}, \mathrm{P}\},\{\mathrm{M}, \mathrm{O}, \mathrm{P}\}$ \\
\hline $\mathrm{N}$ & $\{\mathrm{O}, \mathrm{N}\},\{\mathrm{B}, \mathrm{I}, \mathrm{C}, \mathrm{N}\}$ \\
\hline $\mathrm{O}$ & $\{\mathrm{A}, \mathrm{S}, \mathrm{C}, \mathrm{F}, \mathrm{O}\},\{\mathrm{A}, \mathrm{B}, \mathrm{I}, \mathrm{O}\}$ \\
\hline $\mathrm{D}$ & $\{\mathrm{C}, \mathrm{L}, \mathrm{D}\},\{\mathrm{S}, \mathrm{E}, \mathrm{C}, \mathrm{D}\}$ \\
\hline $\mathrm{K}$ & $\{\mathrm{S}, \mathrm{G}, \mathrm{K}\},\{\mathrm{S}, \mathrm{E}, \mathrm{J}, \mathrm{K}\}$ \\
\hline
\end{tabular}

\subsection{Pencarian Frequent Itemset}

Berikutnya adalah menentukan nilai support setiap transaksi. Setelah mendapatkan nilai Support setiap barang, langkah selanjutnya adalah menyeleksi nilai support yang memenuhi nilai Treshold yang penulis tetapkan adalah 20\%, sehingga barang yang nilai supportnya di bawah $20 \%$ akan dihilangkan, dan dapat kita lihat pada tabel berikut.

Tabel 6. Nilai Support Barang memenuhi Treshold

\begin{tabular}{ccc}
\hline KODE BARANG & FREKUENSI & SUPPORT \\
\hline A & 12 & $40 \%$ \\
S & 10 & $33 \%$ \\
B & 7 & $23 \%$ \\
M & 7 & $23 \%$ \\
E & 6 & $20 \%$ \\
G & 6 & $20 \%$ \\
I & 6 & $20 \%$ \\
\hline
\end{tabular}

Setelah dilakukan seleksi sebagaimana tabel diatas, jenis barang yang akan diteliti hanya berjumlah 7 yaitu kode barang A, S, B, M, E, G dan I sesuai urutan frekuensi dan nilai support terbesar.

Berikutnya adalah menentukan transaksi dengan 2 itemset sebagaimana tampak pada tabel berikut 
Tabel 7. Transaksi 2 itemset

\begin{tabular}{cccccccc}
\hline $\begin{array}{c}\text { KODE } \\
\text { BARANG }\end{array}$ & A & S & B & M & E & G & I \\
\hline A & 1 & 2 & 3 & 2 & 1 & 4 & 2 \\
S & 2 & 1 & 2 & 2 & 3 & 2 & 2 \\
B & 3 & 2 & 1 & 1 & 0 & 1 & 3 \\
M & 2 & 2 & 1 & 1 & 0 & 0 & 2 \\
E & 1 & 1 & 0 & 0 & 1 & 1 & 0 \\
G & 4 & 2 & 1 & 0 & 1 & 1 & 0 \\
I & 2 & 2 & 3 & 2 & 0 & 0 & 1 \\
\hline
\end{tabular}

Berdasarkan tabel di atas, 2 itemset yang paling sering dibeli adalah barang A dan $\mathrm{G}$ dengan 4 kali frekuensi. Adapun nilaisupportnya adalah $13 \%$.

\subsection{Pengujian Pada Software Data Mining Weka}

Berikut adalah langkah-langkah pengujian.

1. Buka aplikasi Weka, sebagaimana gambar berikut.

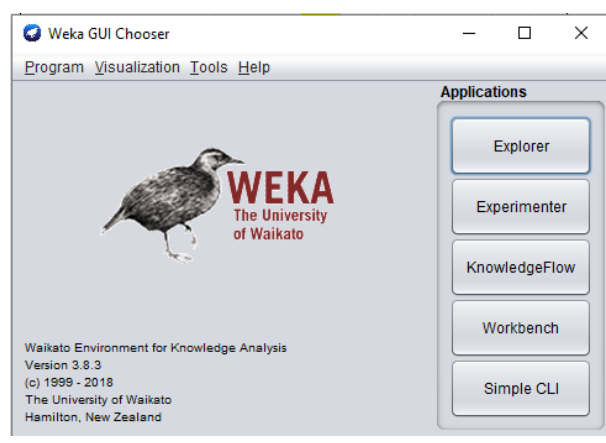

Gambar 3. Interface Weka

2. Pemanggilan data melalui menu Explore.

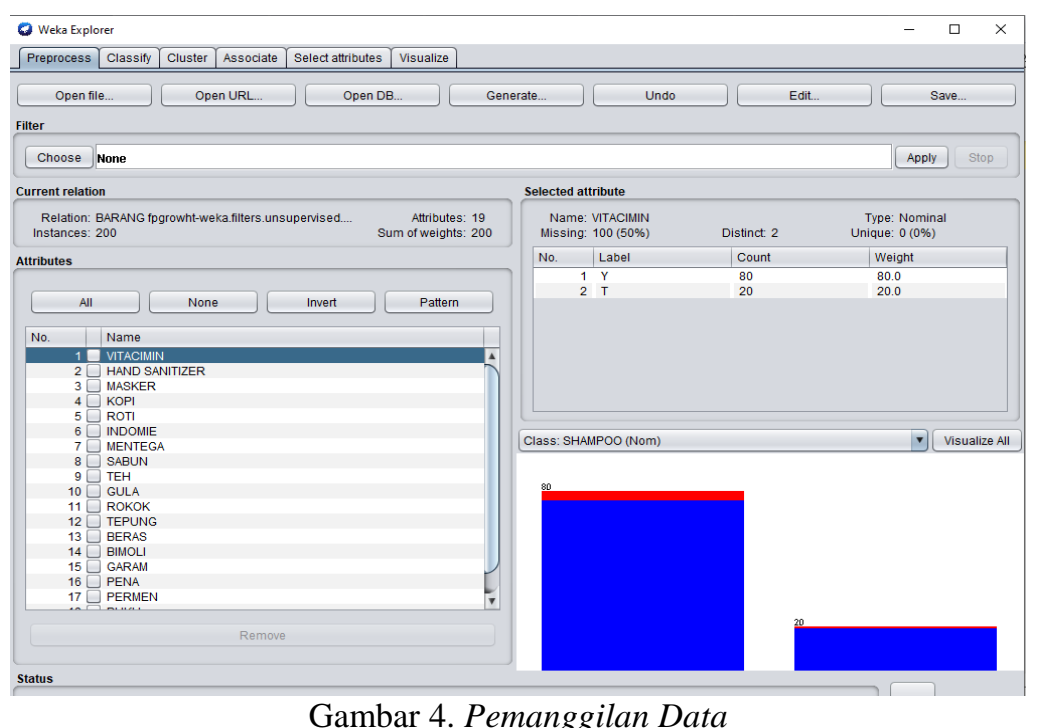

Gambar 4. Pemanggilan Data 
3. Memilih menu Associate dan algoritma FP-Growth dan rule yang terbentuk.

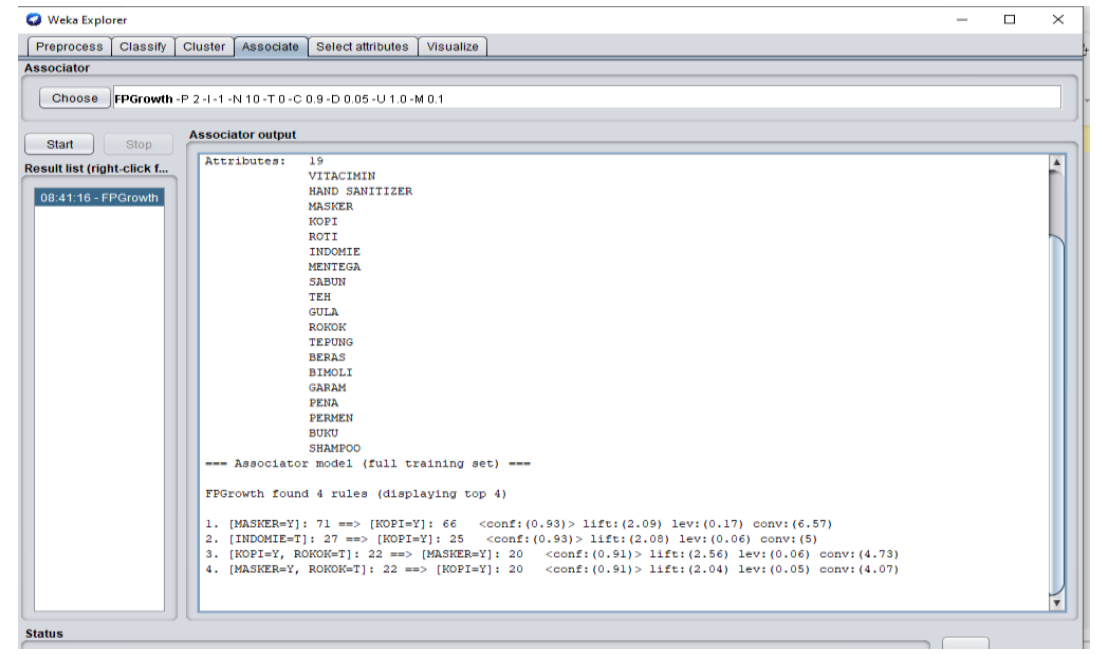

Gambar 5. Rule yang terbentuk dari Algoritma FP-Growth

\section{Kesimpulan}

Berdasarkan pembahasan di atas, kesimpulan yang dapat diambil adalah, algoritma $F P$-Growth memiliki kecepatan dalam pemrosesan data yang terbantu dari pembentukan FP-Tree. Pengujian menggunakan software data mining Weka didapatkan 4 rule terbaik. Kombinasi Masker dan Kopi memiliki support $10 \%$ dan confidence mencapai 93\%. Hal ini membuktikan bahwa produk Masker dan Kopi merupakan kombinasi pembelian yang paling sering dibeli oleh konsumen pada Ghania Mart Muara Bulian.

\section{Daftar Rujukan}

[1] A. Anas, "Implementasi Algoritma FP-Growth Untuk Menentukan Strategi Promosi STIE-Graha Karya Muara Bulian,” J. Ilm. MEDIA SISFO, vol. 14, no. 1, pp. 64-70, 2020.

[2] F. Fitriyani, "Implementasi Algoritma Fp-Growth Menggunakan Association Rule Pada Market Basket Analysis," J. Inform., vol. 2, no. 1, 2016.

[3] C. E. Firman, "Penentuan Pola Yang Sering Muncul Untuk Penjualan Pupuk Menggunakan Algoritma Fp-Growth," I N F O R M a T I K a, vol. 9, no. 2, p. 1, 2019.

[4] F. Nirma, S. Damanik, A. Sagita, and A. Syaputra, "Aplikasi Pengenalan Pola Pembelian Konsumen Menggunakan Kombinasi Algoritma FP-Growth Dan ECLAT,” J. SIFO Mikroskil, vol. 19, no. 2, pp. $1-12,2018$.

[5] A. Junaidi, "Implementasi Algoritma FP-Growth dan FP-Growth Untuk Menentukan Persediaan Barang," J. Sisfokom (Sistem Inf. dan Komputer), vol. 8, no. 1, pp. 61-67, 2019.

[6] A. Maulana and A. A. Fajrin, "Penerapan Data Mining Untuk Analisis Pola Pembelian Konsumen Dengan Algoritma Fp-Growth Pada Data Transaksi Penjualan Spare Part Motor,” Klik - Kumpul. J. Ilmu Komput., vol. 5, no. 1, p. 27, 2018.

[7] Ikhwan, "Penerapan Data Mining dengan Algoritma Fp-Growth untuk Mendukung Strategi Promosi Pendidikan ( Studi Kasus Kampus STMIK Triguna Dharma )," Saintikom, vol. 14, no. 3, pp. 211226, 2015.

[8] R. Fitria, W. Nengsih, and D. H. Qudsi, "Implementasi Algoritma FP-Growth Dalam Penentuan Pola Hubungan Kecelakaan Lalu Lintas,” J. Sist. Inf., vol. 13, no. 2, p. 118, 2017.

[9] B. S. Hasugian, "Penerapan Metode Association Rule Untuk Menganalisa Pola Pemakaian Bahan Kimia Di Laboratorium Menggunakan Algoritma FP-Growth ( Studi Kasus di Laboratorium Kimia PT . PLN ( Persero ) Sektor Pembangkitan Belawan Medan ) Buyung Solihin Hasugian Universitas," J. Ilmu Komput. dan Inform., vol. 6341, no. November, pp. 56-69, 2019.

[10] Ririanti, "Implementasi Algoritma Fp-Growth Pada Aplikasi Prediksi Persediaan Sepeda Motor ( Studi Kasus Pt . Pilar Deli Labumas ),” Pelia Inform. Budi Darma, vol. VI, no. 1, pp. 139-144, 2014. 